\title{
Aesthetic Multilingualism as Ontological Relativism Milorad Pavićs Dictionary of the Khazars and \\ Mark Z. Danielewski's House of Leaves
}

\author{
Andreas Hudelist \\ University of Graz (Austria)
}

\begin{abstract}
The text is brought to life through reading. This has not only been understood by literary scholars like Wolfgang Iser or Umberto Eco, but also by authors or poets. This can be recognized in some literary texts when, from the first page, the reader is forced by the author to actively shape the story to be read. The concept of fold, coined by Gilles Deleuze and Félix Guattari, seems to take into account many strategies of authors to stimulate the negotiation process between author and reader. By fostering non-linear and parallel stories, which lead to many worlds interpretation, the agency of the reader comes to
\end{abstract}

its fore. We can observe very different strategies like this for example in novels of Mark Z. Danielewski and Milorad Pavić. Using the concepts of Deleuze and Guattari, I want to explore how multilingualism can be understood aesthetically and how it leads us to an ontological relativism in literature.

Keywords: Many Worlds Interpretation, Aesthetic Multilingualism, Ontological Relativism, Fold, Milorad Pavic, Mark Z. Danielewski

(c) by the author; andreas.hudelist@uni-graz.at

Colloquium: New Philologies, Volume 5, Issue 2 (2020)

doi: 10.23963/cnp.2020.5.2.7

Stable URL: https://colloquium.aau.at/index.php/Colloquium/article/view/126

This work is licensed under a Creative Commons Attribution 4.0 International License (CC BY 4.0). 


\section{From Aesthetic Multilingualism to Many Worlds Interpretation}

To tell a story means to construct a fable or to find a red thread, which helps the listener to understand what has been said. To tell a story always means to respond to the other. Telling a story always means giving something away. You give something away and you can no longer control it. Because the story you have told, whether in an oral, written, or in any other form, is now part of another story. It becomes now part of the listener's story. This is where the multiplication of meanings begins, which at the same time multiplies the story. This paper focuses on this multiplication, which starts from an aesthetic multilingualism.

At first sight, multilingualism relates to the use of more than one language. Guadalupe Valdés uses multilingualism and bilingualism as synonyms and argues: "for a broad definition that views bilingualism as a common human condition that makes it possible for an individual to function, at some level, in more than one language. The key to this very broad and inclusive definition of bilingualism is 'more than one"' (Valdés n.d.). Aesthetic multilingualism therefore means perceiving the environment in more than one form of experience. In this paper, the term aesthetic is used to refer to modalities of perception. Aesthetic experience is a very special kind of way of experiencing. In connection to multilingualism, we have to argue that one is confronted with more than one single experience or more than one modality.

If we follow the discussion of the history of reception, we notice how the confrontation between audience and artists has never been a confrontation between individuals or the confrontation in the same language. The discourse of art or artistic creation has always been a discourse of power, ever since art has been in contact with the public. The author or the discourse of authors has always been created to exclude people (cf. Hudelist 2020, 34-54). Maybe it is therefore that Roland Barthes reminds us that the idea of an author was a creation of modernity. This idea of an author even led Barthes to the provoking paper "The Death of the Author". He lets the author die so that the sovereignty over the possibilities of interpretation can no longer be attributed to an individual (cf. Barthes 1977). Thus, the concept of the author or the term itself can, like the notion of the work, both constrict the meaning and interpretation as well as open the text. Ultimately, the text is enlivened by the dialogue between producer and recipient. Rather, the focus seems to be on pausing and amazement, i.e. the decelerating act of reading by the reader. The aesthetic experience is characterized by the fact that it is fundamentally paradoxical. Text and approach are different in their dimensions of experience and must first find their way to each other. The result of a reading cannot be predicted, since neither the text nor the ego has a singular origin. The moment of astonishment arises in a process of encountering something new, although it is seldom certain what this newness actually 
encompasses (cf. Hudelist 2017, 135). But in this way the ego, like the text, is formed from the plurality of other texts that set the stone of playful identity formation rolling. An open text outlives the author and creates unlimited possibilities for interpretation and discourses, because the language it uses is always adopting and changing. It is these unlimited possibilities that make a democratic contribution to society or as in this case, to the art world. However, how the text is dealt with in this process cannot be predicted. In this manner, texts are characterized by their openness, which at the same time means their indeterminacy. In his text The Open Work, Umberto Eco argues for a new understanding of aesthetic perception. "In short, it [the open work, A.H.] installs a new relationship between the contemplation and the utilization of a work of art" (Eco 1989, 23). As an example, Eco draws on the writings of James Joyce to address also how works of art (can) deal with everyday experience, and therefore with the process of everyday language. Thus, A Portrait of the Artist as a Young Man is a novel about the way we deal with words in our everyday life and the realization that we no longer want to submit to their power. In the power of words lies a certain kind of ideology. While speaking, this ideology is incriminated in the words and thus at the same is passed over. Considering this, in Joyce's first novel the protagonist Stephen Dedalus explains to his friend Cranly from University College Dublin what kind of freedom he means when he no longer wants to be a servant:

I will tell you what I will do and what I will not do. I will not serve that in which I no longer believe, whether it call itself my home, my fatherland, or my church: and I will try to express myself in some mode of life or art as freely as I can and as wholly as I can, using for my defence the only arms I allow myself to use - silence, exile, and cunning. (Joyce 1996, 281)

Cranly fears the possibility of Stephen's loneliness, because those who seek freedom detach themselves from many things and the solution of home, fatherland or church leaves one, not only Cranly, disoriented for the time being. Stephen, who dedicates himself to his namesake after art, sees in it a possible freedom to express himself completely. This is accompanied by a deep mistrust of language, which structures thinking and thus limits a person's expressiveness. The possibilities of art should allow different languages and thus a cunning escape. Eco describes this as the openness of the artwork, which promises both artists and recipients of art different surprising qualities of perception and forms of expression.

These poetic systems recognize 'openness' as the fundamental possibility of the contemporary artist or consumer. The aesthetic theoretician, in his run, will see a confirmation of his own intuitions in these practical manifesta- 
tions: they constitute the ultimate realization of a receptive mode which can function at many different levels of intensity. (Eco 1989, 22)

In the logic of the open work of art, expressive possibilities are not restricted, but rather attempted to expand. Every possible reading is thus welcome and encouraged by the form of an aesthetic multilingualism. This follows also the approach of the experience of quantum mechanics, when it is stated that there is only one physical world, but at the same time "there are two incompatible stories about that world" (Albert 1992, 115). Postmodern literature, if this term may be assigned as a literary identifier, deals confidently with this fact and transfers it into the literary aesthetics of a many worlds interpretation.

\section{Dictionary of the Khazars}

Milorad Pavićs first book Dictionary of the Khazars was published in the year 1984. We do not know much about the Khazars except that they were a nomadic people between the Caspian and Black seas and apparently vanished around the $10^{\text {th }}$ century. "The stories about the Jewish Khazars could simply be regarded as fantastic tales or legends" (Stampfer $2013,1)$. It seems that Pavić was inspired by this lack of knowledge about the Khazarians to broach the issue of the inter-ethnic religious ties of the people, but also beyond that, the fate of the entire people, which seems to simply disappear in history.

The content of the book apparently relates to events that took place between the $8^{\text {th }}$ and $9^{\text {th }}$ centuries and is based on the Khazar polemic. The story of the nomadic tribe of the Khazars is told in different versions. In the preliminary notes we can read:

The Khazars, and the Khazar state, vanished from the stage of history as a result of the event that is the main concern of this book - their conversion from their original faith, unknown to us today, to one (again, it is not known which) of three known religions of the past and present - Judaism, Islam, or Christianity. (Pavić 1996a and 1996b, 2)

All three chapters, which are titled as books (the red book based on Christian sources, the green book based on Islamic sources, and the yellow book based on the Hebrew sources) are organised like a lexicon. Within the preliminary notes we learn how to use the book, can read an introduction about a history of the Khazar dictionary itself, and after the three dictionaries we are able to find an appendix. Following Tatjana Aleksić, these conflicting stories arise from a mythistorical event, which leads to "the impossibility of distinguishing between the historicity as opposed to the mythological origins of nationalist, religious, or other kinds of narratives of origin" (Aleksić 2009, 86). We do not know to 
which religion the Khazars turned, although it seems to be one of the three monotheistic religions. One has also forgotten to which religion the Khazars originally belonged. However, interestingly enough, this seems to be a minor issue. Before the $9^{\text {th }}$ century, there is no history. The encyclopaedic entries only deal with the time after the year 1982. In the Christian sources, we read about Dr. Isailo Suk (1930-1982), who was university professor at Novi Sad as archaeologist and Arabist. He is the owner of an edition of the Khazarian Dictionary and is sure that he held a poisoned original in his hands, where the reader would die after having read nine pages, so he never read more than four pages. Dr. Abu Kabir Muawia (1930-1982) is the protagonist of the Islamic source. He was working as an Arab Hebraist at Cairo University and was convinced that there are at least two editions of the Khazarian Dictionary. He dedicated his academic career to the reconstruction of the book distribution in the $17^{\text {th }}$ century and created a list of books destroyed and put on the market. In Istanbul, where he wanted to find out more about the Khazar story, someone unknown shot him. Slavist and university professor in Jerusalem Dr. Dorota Schulz was born 1944, but we know nothing about her death. Rather, we gain a glimpse into the letters that she, living alternately in Tel Aviv and Jerusalem, sent herself to Poland, to her former address. The letters were written between 1968 and 1982 and deal with the Khazar polemic. Moreover, the letters deal also with her meetings with both Isailo Suk and Abu Kabir. The latter she planned to kill, but she could not, because Kabir tells her about his findings of Cyril's Khazar Orations, which was a great discovery in the academic field. Interestingly, this page in the book contains the paragraph that differs in the two versions of Pavićs Dictionary of the Khazars. In the female version, it says:

As he passed them to me, his thumb brushed mine and I trembled from the touch. I had the sensation that our past and our future were in our fingers and that they had touched. And so, when I began to read the proffered pages, I at one moment lost the train of thought in the text and drowned it in my own feelings. In these seconds of absence and self-oblivion, centuries passed with every read but uncomprehending and unabsorbed line, and when, after a few moments, I came to and re-established contact with the text, I knew that the reader who returns from the open seas of his feelings is no longer the same reader who embarked on that sea only a short while ago. I gained and learned more by not reading than by reading those pages [...]. (Pavić 1996a, 293f)

It is not about the swan song of literature, but about paying homage to literary aesthetics, which can freeze and expand time simultaneously. Literature here becomes a fold in 
which ends that are suddenly far apart are able to touch each other. Following Deleuze, this is an essential characteristic of a labyrinth: "The unit of matter, the smallest element of the labyrinth, is the fold, not the point which is never a part, but a simple extremity of the line. [...] Unfolding is thus not the contrary of folding, but follows the fold up to the following fold" (Deleuze 2006, 6). In this example with the three different sources on the Khazar question, we see how once incompatible narratives come together and complement each other in such a way that they can never again be read without the other. However, the author of the book did not want to rely solely on the reading skills of the readers, but referred to this passage at the end and makes it clear that in case we still did not know, that there are two versions, female and male, of the book. In the "closing note on the usefulness of this dictionary", we can read about the quoted passage above in both versions of the book: "They are different. When they compare the short passage in Dr. Dorothea Schultz's last letter, printed in italics in the one and the other exemplar, the book will fit together as a whole [...]" (Pavić 1996a and Pavić 1996b, 335). In the male version we read:

I could have pulled the trigger then and there. There wouldn't be a better moment. There was only one lone witness present in the garden - and he was a child. But that's not what happened. I reached out and took those exciting sheets of paper, which I enclose in this letter. Taking them instead of firing my gun, I looked at those Saracen fingers with their nails like hazelnuts and I thought of the tree Halevi mentions in his book on the Khazars. I thought how each and every one of us is just such a tree: the taller we grow toward the sky, through the wind and rain toward God, the deeper we must sink our roots through the mud and subterranean waters toward hell. With these thoughts in my mind, I read the pages given me by the green-eyed Saracen. They shattered me, and in disbelief I asked Dr. Muawia where he had got them. (Pavić 1996b, 293f)

The quotations show different gender stereotypes. The male version contains a more martial description of the events, in which we get to know more about the protagonist's outer world and through this description learn about the setting of the murder. The analogy of the tree of Halevi refers to a single movement, which goes in different directions - both toward the sky and toward hell. Again, here we can find the unfolding of a fold, leading us to the next fold(s). These could be among other passages, the trial of the murder case, or the next lexicon entry on Tibbon, Judah Ben, who was the translator of Judah Halevi's "Book on the Khazars". In the second appendix, we find the excerpt from the court minutes, which deal with the murder of Abu Kabir. In this way, we learn of a calculation as 
evidence which contains the addition of 1689 plus 293, equalling 1982. Interestingly, the difference of 293 leads to the page number leads to the page in the book with the only difference between the female and male versions. Furthermore, we learn about the authors of the three different books, based on the different religious sources, that all three died in the year 1689. The Christian Avram Brankovich (1651-1689) was a diplomat in Edirne, a military commander, a polyhistor and a learned man. Like the other two, he was researching the Khazars. Yusuf Masudi (mid-1 $7^{\text {th }}$ century to 1689) was a famous flute player but also one of the writers of the Islamic sources on the Khazar question. The last one is Samuel Cohen (1660-1689), a Dubrovnik Jew, who is one of the authors of the Hebrew sources on the Khazar question. As we can understand, one fold leads to another and unfolding becomes opening a labyrinth where, with every new fold, the exit seems further away than before. If we take, for example, the tree described by Judah Halevi, we could not only find the tree of life, but also a correspondence in another book, in which just this tree in a similar quality gives an idea of the structure(s) of the text, although again different from Dictionaries of the Khazars. The book to be referred to at this point is Daniel Z. Danielewski's debut and is entitled House of Leaves.

\section{House of Leaves}

Mark Z. Danielewski's first novel House of Leaves, published in 2000, might be viewed as a particularly good example of ontological relativism in literature. Since it is marketed as a novel, the question arises as to the extent this book could actually be considered a novel and in which directions the boundaries of the genre are tested, for the book shows manifold folds, which in turn make the manifold visible. Danielewski wrote his text as someone who knows about past and present literary theory. House of Leaves is therefore not a literary text that can be made accessible through literary theory, since the text is already a commentary on literary theory itself. What there is to say about the text is already said by the text itself; it is always at a distance from itself as Zubarik (cf. 2014, 233) points out. House of Leaves seems to be an academic text that deals not only with the strange phenomenon of the house, but also with the editorial work of several different editors. Raymond Federman calls the implementation of such footnotes in a fictional book "critifiction" (Federman 1995). The story of the house is framed within Zampanòs text, which is framed through Johnny Truant's comments, associations and his own approach to the topic, which is framed by the unnamed editors. The role of the author Mark Z. Danielewski is not commented on. However, there is a publishing team that edits the text of Truant, who found the records of Zampanò, who documented a lost film in writing: “The Navidson Record”. “The Navidson Record” is actually not a complete film, 
but film sequences of Will Navidson and helpers who wanted to explore the inner life of a house that was constantly changing its architectural foundations. Two films emerged from this exploration. One was the "Five and a Half Minute Corridor" and the other "Exploration No. 4". The house that this story is about was bought by the Navidson family, who after a while found out that it has an interior life of its own that is far beyond the imagination and spatial potential seen from the outside. In other words, the dimensions of the rooms inside the house exceeded the dimensions of the house as seen from the outside.

The Navidson family comes home one evening and notice after entering that the house's interieur looks different than before. When they call the police, they feel more helpless than before, when one of the officers explains: "We'll file a report but other than that, well I don't know what more we can do. Better I guess t' have been a victim of a crazy carpenter than some robber" (Danielewski 2000, 29). Here we are confronted with a riddle that begins with the book. When Navidson takes a book off the shelf, the house begins to live and change.

A novel. Just as with Karen, its removal causes an immediate domino effect. Only this time, as the books topple into each other, the last few do not stop at the wall as they had previously done but fall instead to the floor, revealing at least a foot between the end of the shelf and the plaster. Tom thinks nothing of it. Sorry, he mumbles and leans over to pick up the scattered books. (ibid, 40)

Here the question arises as to what literature can do or effect. The use of the novel as a doorstop brings with it an unpredictable change in the house. Maybe this can be seen as a metaphor for reading in general. Reading has an influence, because readers can accept and expand a story, but they are also able to reject what they read. The text offers resistance to the reader's accustomed viewpoint. Maybe the author Danielewski had in mind to play with various perspectives in one story. This is the central theme of the novel House of Leaves, where if one leaf is lost, the next one grows back in different ways. One could call the story of the house a core story, which Navidson captured on film and Zampanò documented in writing before all the film documents were lost. Johnny Truant, who looked through Zampanòs descriptions of the filmic text and commented again, determines the fourth layer of the narrative 'onion'. The editors, who appear to be as restrained as possible and only highlight errors or provide additional information according to their own perception, provide the final framework. Based on the framing, one could conclude that this is a classical onion structure, where you can follow the narrative(s) in a linear way. However, the House of Leaves narrative is not the most quantitatively comprehensive and is only the starting point for many other stories and associations, although the 
story of Truant is perhaps quantitatively most strongly developed in the book. This quantity turns the history or rather the chronology of the layers a little bit upside down, because it could be that "The Navidson Record" is not only a phantom of Zampanò, but also includes Zampanòs phantoms of Truant. Thus, Truant's story would be the core and starting point of the narrative and the chronology, which not only provides a temporal order but also a linear hierarchical order. This, however, is disturbed by the fact that the starting point of the narrative moves simultaneously towards two ends. First, the beginning of the house's story and second, the work of the editors, who were trying to make sense of it all. Here it is then no longer possible to start from a single basic text.

It may well be that a reference to the concepts of Gilles Deleuze or even Deleuze and Félix Guattari is hidden in the literary form. In Deleuze's book The Fold: Leibniz and the Baroque, there are several ideas that can also be found in the book House of Leaves. For example, that there is no beginning and no end, because only by stratifying the stories told to us in the book can we guess a chronology, but we cannot be sure that this is how it will go. Every time we read the book, we will go another way, because the chronology of the reading can never be assured. Another argument that stands for Deleuze's notion of the fold is the implementation of the concept both in terms of content in and form of the book. An analogy that both Danielewski and Deleuze use is that of the labyrinth. "A labyrinth is said to be multiple, etymologically, because it has many folds. The multiple is not merely that which has many parts, but that which is folded in many ways" (Deleuze 1991, 228). These folds can be traced visually and in the flow of reading, for example, when the reader no longer reads from left to right, but repeatedly adds the annotations in the footnotes, whereby footnotes also have footnotes and are not always to be read according to their numerical sequence, but in a jumbled manner. In chapter twelve for example, the book must additionally be turned 180 degrees, so that the main text can be read further. In chapter nine, the labyrinth is translated into the layout, because the main text has to make room for three more text blocks. Such blocks are, for example, the footnotes at the end of the sheet, a whole column containing italic footnotes at the right margin, and finally there is a square text window, which collects objects in terms of content, which are not available in the house. Sometimes the footnote texts become the main text and take up the entire page, sometimes pages are divided into footnote inserts only, which are found vertically, horizontally and in reflections. On page 159, there is even a footnote in the fold of the book, so that it could easily be overlooked.

Mark Danielewski's text House of Leaves is not about placing a narrative or narration in the foreground, but on the contrary, these recede into the background and make room for a many stories world form. It is about giving way to form, indicating the impossibility of telling a story. However, the form and manner in which this narrative recedes into the 
background, through remembering, through narration, shows that the narrative itself fails and the impossibility of one narration becomes transparent.

Maybe this is also the reason why we find a visual poem at the end of the book after the appendix, the index, and the credits. It is a tree that has similarities to the one in Pavićs text.

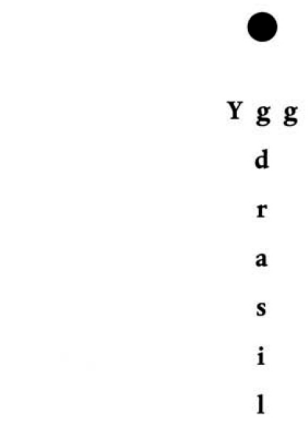

\footnotetext{
What miracle is this? This giant tree.

It stands ten thousand feet high

But doesn't reach the ground. Still it stands.

Its roots must hold the sky.
}

$\mathbf{O}$

Figure 1: Danielewski 2000, 709.

We can say that also here the tree refers to the tree of life, like the tree in The Dictionary of the Khazars, because there is a definite corresponding similarity in terms of movement. Here, too, the tree is used as an analogy to describe seemingly impossible things: one movement in different directions. Although the tree seems to be rooted in heaven, it stands still and is not marked by movement. The visual arrangement of the word Yggdrasil suggests rooting at the top and the tree crown at the bottom. Yggdrasil is a mythical tree from Nordic cosmology and refers to nine worlds. Yggdrasil means the bearer of Ygg (Odin) and is not only the centre of our biosphere, but is our biosphere, where it is not possible to divide between living organism and the living cosmos. The truth is apparent everywhere. Both content and form are one (cf. Allen 1969, 311). In one respect, therefore, House of Leaves, can be read as the content of the book. For example, the house loses a hallway or a room and a new one grows in its place. On the other hand, the title of the book is also related to its form. The analogy of the house shows that 
the book cannot be walked through along only one path. The chapters make branches possible and allow back entrances or permit one to enter from different chapters.

\section{Many worlds interpretation and ontological relativism}

So far, we have been able to learn a lot about the different folds that lead us through the book and allow for different approaches to the stories, but only implicitly reflected on the form. In its form, the dictionary allows for different approaches without placing one above the other. The aesthetic form of the dictionary makes multilingualism possible by mediating between different experiences and modes of perception. Becoming acquainted with the different stories leads the reader further and deeper into the story, whereby the story does not become more comprehensible and complete, but more empty spaces are created and new questions are raised. In this way, a relativism arises, which results from the manifold potential and constantly allows for new possibilities to be produced.

Both described insights into the text examples only give a fraction of what can be experienced during reading the texts. In these complex, self-referential structures, one is always led in a circle, whereby the place where one started in the circle before has already changed again with each new arrival. In the context of sound, Nina Dragičević describes the doppler effect, which makes the sound of a car appear as if it is moving away and coming closer at the same time (cf. Dragičević 2018, 23). The literaturary examples discussed here show this special kind of folding, which leads us in two opposite directions, sometimes even mutually exclusive directions or experiences. Milorad Pavić finds the fact of these potentially infinite and conflicting interpretations appealing. As an author, he automatically instantiates himself more and more from his books, the more time passes, and is thus completely in line with Barthes.

Yes, I always think of my reader. I offer him a choice - millions of possible paths for reading. And, the more the book he has read differs from the one I have written, the better I have dealt with my task. Today I perceive myself less as the author of Dictionary of the Khazars than I did yesterday and less still than the time I was actually writing the novel. Besides, if you want to write a new book you have to get rid of the previous one. That's why I'm becoming less and less the author of my books, and the day will come when I completely stop being one; I'll be much more distant from my own work than any of my readers. I find it wonderful and it cheers me no end. (Pavić and Slapins 2006)

While the readers become more and more intimate with the text, Pavić becomes more distant. For him, it is not about finding out what the author wanted to say, but to find 
something new between the words, something the author never could have thought of. Here he follows Danielewski, who describes the potential of a many worlds interpretation in the brickwork of writing.
It's this understanding of how text can offer a music that is free of the shack- les of shape and hue. At the same time, the image in my mind seems so light in its air of irresponsibility toward the labor of text - the brickwork, if you will. Writing is so much about laying down brick after brick, and yet you can't just stack bricks, because then you're making a tomb. There has to be this mortar, and that mortar, as we can see for ourselves, right now even, is the space between words. (Danielewski and O'Riley 2012/2013, 72)

As we can see in both statements, the function of the author lies in the deconstruction of a possible authority by softening, as far as possible, given structures of the novel, of writing and reading, and approximating the practice of the reader. Both texts discussed in this contribution showed, although only a small insight into the form and content was possible, that an intensive examination of their aesthetic multilingualism is necessary to understand how an ontological relativism may appear.

Both examples have some similar properties. Both books contain instructions on how to deal with them or with their collections of texts. In both, one learns about the genesis of the novel and receives additional information that is not usual for the genre. Thus, appendices are added, which also include letters, photos, collages, indexes, court typescripts and concluding remarks. Both 'novels' are also said to be based on an original, which has been destroyed. Original readers had to pay with their deaths in both cases. Also, in the texts themselves, there are readers of the respective text who are found dead shortly afterwards. Footnotes, often referring to sources outside the novels, are useful extensions in both cases, although not to the same extent. It is equally interesting that both authors are said to have worked with the idea of hypertext.

The lexicon was the first type of text ever to come into contact with hypertext when it appeared on CD-Rom. Hypertext as a literary phenomenon arises in the 1980s and The Dictionary of the Khazars has such qualities that the reader becomes a co-author (cf. Cotkin 1996, 108). Danielewski used the advanced technology and has his readers actively continue writing House of Leaves on the Internet. In the text itself, he pays tribute to the hypertext aesthetics by, for example, placing the word house in blue letters without exception. In addition, Danielewski creates a special feature with the quantitative arrangement of the footnotes: the reader always has to decide whether to continue reading the footnote or the next chapter (cf. Hemmingson 2011, 281). Moreover, also on the Internet, lines of the book can be read in a forum and discussed beyond their spatial confines in the book. Danielewski has set up a forum on his homepage for each of 
his books, so that the way through the labyrinth is continued in different languages (see online: http://forums.markzdanielewski.com/forum/house-of-leaves). With Umberto Eco, we find the described characteristics again in the 'open work of art', which aesthetics intentionally open up for manifold interpretations. Eco does not ask the question whether the artist or the audience creates the meaning of the work. The focus is on the encounter, whereby interpreters enrich the work of art at the moment they are conveyed by their makers (cf. Eco 1973, 29). The open work of art will never be completed- one more reason to open/unfold the novels and to start again at the beginning. But the beginning has already changed.

\section{Literatur}

Albert, David. 1992. 2uantum Mechanics and Experience. Cambridge/London: Harvard University Press.

Aleksić, Tatjana. 2009. "NATIONAL DEFINITION THROUGH POSTMODERN FRAGMENTATION: MILORAD PAVIĆ’S DICTIONARY OF THE KHAZARS.” In The Slavic and East European Journal, (1): 86-104.

Allen, Rupert C. 1969. "Juan Ramón and the World Tree: A Symbological Analysis of Mysticism in the Poetry of Juan Ramón Jiménez.” In Revista Hispánica Moderna, (4): 306-322.

Barthes, Roland. 1967. "The Death of the Author." In Image, music, text, 142-148. London: Fontana Press.

Cotkin, George. 1996. "'Hyping the Text': Hypertext, Postmodernism, and the Historian." In American Studies, (2): 103-116.

Danielewski, Mark Z. 2000. House of Leaves. 2nd edition. New York: Pantheon.

Danielewski, Mark Z.n.d. House of Leaves. Accessed: 5 March 2020. http://forums.markzdanielewski. com/forum/house-of-leaves

Danielewski, Mark Z. and Christopher O’Riley. 2012/2013. „Mark Z. Danielewski“. In Bomb, (122): 70-75.

Deleuze, Gilles. 1991. "The Fold." In Yale French Studies, (80): 227-247.

Deleuze, Gilles. 2006. The Fold: Leibniz and the Baroque. London: continuum.

Dragičević, Nina. 2018. "The shallow throat and the grand composition." Accessed: 5 March 2020. http://mfru.org/simpozij/nina-dragicevic/

Eco, Umberto. 1989. The Open Work. Cambridge, Massachusetts: Harvard University Press.

Federman, Raymond. 1995. Critifiction. Albany: SUNY P.

Hemmingson, Michael. 2011. "What's beneath the Floorboards: Three Competing Metavoices in the Footnotes of Mark Z. Danielewski's House of Leaves." In Critique: Studies in Contemporary Fiction, (3): 272-287.

Hudelist, Andreas. 2017. "Der Leser als Produzent? Postmoderne Identifikationen in der Literatur (am Beispiel von jemandem, der sich unter anderem Flann O'Brien nennt).“ In IchErzählungen. Narrative Identitäts/De/Konstruktionen, 120-138. Innsbruck/Wien/Bozen: StudienVerlag. 
Hudelist, Andreas. 2020. Im Gefüge der Kunst. Affektive Performativität als kreative Praktik. Bielefeld: transcript.

Joyce, James. 1996. A Portrait of the Artist as a Young Man. Reading, Berkshire: Penguin.

Pavić, Milorad. 1996a. Dictionary of the Khazars. A Lexicon Novel in 100,000 words. The female edition. Belgrade: Dereta.

Pavić, Milorad. 1996b. Dictionary of the Khazars. A Lexicon Novel in 100,000 words. The male edition. Belgrade: Dereta.

Pavić, Milorad and Ilmars Slapins. 2006. "The world from the viewpoint of Milorad Pavic." Accessed: 4 March 2020. https://www.eurozine.com/the-world-from-the-viewpoint-of-miloradpavic/

Stampfer, Shaul. 2013. "Did the Khazars Convert to Judaism?” In Jewish Social Studies, History, Culture, Society, (3): 1-72.

Valdés, Guadalupe. N.d. "Multilingualism." Accessed: 4 March 2020. www.linguisticsociety. org/resource/multilingualism

Zubarik, Sabine. 2014. Die Strategie(n) der Fußnote im gegenwärtigen Roman. Bielefeld: Aisthesis. 